\title{
The effects of various carbohydrates and tannic acid on the food consumption and growth performance of Uresiphita gilvata (Lepidoptera: Crambidae)
}

\author{
Ender ALTUN ${ }^{1}$, Mahmut BİLGENER ${ }^{1}$ Nurver ALTUN ${ }^{2 * 1}$ \\ ORCID: 0000-0001-6072-2302; 0000-0001-7883-6973; 0000-0002-2657-9263
}

\author{
${ }^{1}$ Department of Biology, Faculty of Science and Arts, Ondokuz Mayis University, Samsun, Turkey \\ ${ }^{2}$ Department of Biology, Faculty of Science and Arts, Recep Tayyip Erdoğan University, Rize, Turkey
}

\begin{abstract}
The effects of carbohydrates and tannen on the development and food preferences of Uresiphita gilvata larvae were investigated in this study. In addition, with the addition of tannin, the importance of plant-herbivore co-evolution in the food choice of the larvae was mentioned. For this reason, thirteen different artificial diets were prepared. Each diet contains sucrose, glucose, galactose, maltose, fructose, arabinose, mannose, or starch at the same concentration. To investigate the effect of tannic acid, $5 \%$ tannic acid was added to the diets each containing sucrose, starch, glucose or maltose at the same concentration. According to the results of the study, sucrose was consumed by larvae more than glucose and fructose. However, the maximum food consumption of U. gilvata larvae was on the diet containing arabinose and their minimum consumption was on the diet containing mannose. Galactose is more consumed by larvae. However, intake galactose can not converted to pupal lipid by larvae. The addition of tannin to the diet reduced the amount of consumption of diet the dry pupal weight and lipid amount of pupae. However, the addition of tannin to the diet increased the amount of protein and extended the development time of pupae.
\end{abstract}

Key words: carbohydrates, Uresiphita gilvata, tannin, plant-insect interaction, feeding

\section{Çeşitli karbonhidratlar ve tanik asidin Uresiphita gilvata (Lepidoptera: Crambidae)'nın besin tüketimi ve gelişme performansına etkileri}

Özet

$\mathrm{Bu}$ çalışmada, Uresiphita gilvata larvalarının besin tercihi ve gelişiminde karbonhidratların ve tanennin etkisi araştırılmıştır. Ayrıca, tanen ilavesiyle larvaların besin tercihinde bitki-herbivor birlikte evrimleşmesinin önemine değinilmiştir. Bu amaçla, 13 farklı yapay diyet hazırlanmıştır. Herbir diyet aynı konsantrasyonda sükroz, galaktoz, glikoz, maltız, fruktoz, arabinoz, mannoz ya da nişasta içermektedir. Tanenlerin etkisini incelemek için aynı konsantrasyonda sükroz, nişasta, glikoz veya maltoz içeren diyetlere $\% 5$ tanen ilavesi yapılmıştır. Çalışma sonuçlarına göre, larvalar sükrozu, glikoz ve maltozdan daha fazla tüketmiştir. Fakat, U. gilvata larvaları en fazla arabinoz içeren diyeti, en az ise mannoz içeren diyeti tüketmiştir. Galaktoz içeren diyet fazla tüketilmesine rağmen larva tarafından dönüştürülememiştir. Diyete tanen ilavesiyle besin tüketim miktarı, pupa kuru ağırlığı, pupa lipit miktarı azalmıştır. Fakat, pupa protein miktarı artmış, gelişim süresi de uzamıştır.

Anahtar kelimeler: karbonhidrat, Uresiphita gilvata, tanen, bitki-böcek ilişkisi, beslenme

\section{Introduction}

The host preference and the performance of the insect communities are determined by the host plants' qualities [1]. Host plants' qualities are depended upon the plants' protein, carbohydrate, and water contents, along with their secondary metabolites contents [2]. Carbohydrates that contribute to the structures and functions of insect tissues are principal classes of organic compounds for insects and other organisms. In addition to hemolymp of insects,

\footnotetext{
${ }^{*}$ Corresponding author / Haberleşmeden sorumlu yazar: Tel.: +904642236126; Fax.: +904642234019; E-mail: nurver.altun@erdogan.edu.tr

(C) Copyright 2020 by Biological Diversity and Conservation $\quad$ Received: 3.11.2019; Published: 15.08.2020 BioDiCon. 867-1119
} 
carbohydrates are found in the nucleus, cytoplasm, andcell membrane of all cells [3]. They are also used as a nutritional source and general energy source for insects especially in their later larval stages [4-5] which stored them as glycogen and lipids. Feeding with carbohydarate-rich foods contributes to the survival of adults in diapause and the longevity of heterotroph individuals [6]. Basically, glucose, fructose, and sucrose are indispensable carbohydrates as nutritional components for many insect species. But, there are differences in the use of these nutritional carbohydrates among insect species [7]. In addition, some carbohydrate compounds may play a role as a nutritional stimulant for some insect species. Nevertheless, the same carbohydrates may be a nutritional deterrent for other insect species. The nutritional deterrents cannot be completely hydrolyzed or absorbed by some insect individuals [3].

Also, secondary metabolites are very important factors in choosing host plants for feeding and oviposition for insects and various plant secondary metabolites are produced for defensive purposes against herbivores in plantherbivore relationships. As a secondary metabolite, tannins are the most common of phenolic compounds produced by plants [8]. They are accumulated at much lower levels in herbaceous plants than woody dicotyledons. Tannins can bind a wide variety of natural polymeric compounds in vitro, including carbohydrates and lipids [8]. Ingested tannins in plant foods can bind surfactants and can cause a nutritionally significant loss of essential fatty acids [8]. They also affect herbivores by inhibiting insect enzymes. Tannins in an artificial insect diets can be caused a significant decrease in larval performance that is consistent with decreased protein digestion. However, some insect species may have ability to tolerate ingested tannins. The ability of insects to tolerate ingested tannins comes from a variety of biochemical and physical adaptations in their guts, including surfactants, high $\mathrm{pH}$, antioxidants, and a protective peritrophic envelope that lines the midgut [8].

Uresiphita gilvata F. (Crambidae: Lepidoptera) is widely found in Europe, North Africa and in South Africa in Namibia [9]. The ecological importance of this species is the distribution in the Kizılırmak delta. The Kız1lırmak Delta in the Central Black Sea region of Turkey is defined as a Ramsar Area by virtue of its natural habitats and rich biodiversity. Besides playing an important part in both achieving ecological food chains and protecting biological diversity, wetlands are ecosystems that make significant contributions to the economy of regions and countries [10]. The larvae of $U$. gilvata feed on various low-growing herbaceous plants, including Genista, Cytisus and Ulex. Therefore, this insect species is important to maintain ecological diversity.

As pointed out above, carbohydrates may play a role as phagostimulants or deterrents in insects, they are also energetic in their reproductive and developmental processes. Every insect species has been evolved a different adaptation to different carbohydrates. Insect deterrent carbohydrate cannot be completely hydrolyzed or absorbed by insect species. Tannins may decrease protein digestion in insects' guts. Therefore, in this study, the effect of carbohydrate varieties on food consumption and development of this species will be examined. Although there are many woody and herbaceous plants in the habitat of the species, U. gilvata larvae are fed with herbaceous plants. Woody plants protect themselves with secondary metabolites especially tannins. So, in this study; it can be explained that the larvae prefer to feed on herbaceous plant rather than woody plants by adding tannic acid to the diet. Also, which kind of carbohydrate is a deterrent effect on feeding the species can be determined?

\section{Materials and methods}

\subsection{Insects and Experimental Chambers}

U. gilvata larvae were collected from the K1z1lırmak Delta in 2014 while they were feeding on their natural host plant Sophora alopecuroides L. (Fabaceae). The collected larvae were fed on an agar based artificial diet originally designed by Yamamoto [11] until the final instar in the laboratory. Immediately upon molting to the final instar, the individuals were weighed in $0.0001 \mathrm{mg}$ sensitive scale; then each one was placed singly into a plastic cup with a cover. Both the culture and the experimental chambers were kept at the constant temperature at $25 \pm 10 \mathrm{C}, 12 \mathrm{~h}: 12 \mathrm{~h}$ light-dark regime and $65 \pm 5 \% \mathrm{RH}$.

\subsection{The Artificial Diets}

The artificial diet menu developed by Yamamoto [11] was used as the control diet and modified to obtain experimental diets. Sucrose (3\%) was used as a carbohydrate ingredient in Yamamoto's diet. We used one of the carbohydrates (glucose, galactose, maltose, fructose, arabinose, mannose, starch) instead of sucrose in the same concentration in each experimental artificial diets. One of the experimental diets was not contained any added carbohydrate source. By adding an amount of $5 \%$ of tannic acid of total dry weight to the artificial diet; four different artificial diets were prepared to investigate the effects of tannic acid with sugars. Each of these artificial foods having tannic acid contained one of different carbohydrates (sucrose, maltose, glucose or starch). Totally, thirteen experimental artificial diets were prepared this way and were used to the last instar larvae of U. gilvata in the experiment chamber. 


\subsection{Experimental Protocol}

The weight of each of the last instar larva was measured at the beginning of experimental feeding. Each food block prepared as described above was pre-weighed before being presented to the larva for each treatment. A total of ten replicates was used for each diet treatment. Every day, any uneaten food by the larvae remaining in the larval chamber was collected and replaced with fresh pre-weighed food block. The uneaten food left by the larva from each feeding chamber was collected separately and dried in an oven $\left(50{ }^{\circ} \mathrm{C}\right)$ and weighed after it had reached a constant dry weight. Each larva was also weighed daily. This procedure was repeated until all of the larvae entered the pupal stage [12].

\subsection{Pupal Lipid and Protein Analyses}

The total lipid amount in each pupa was calculated by modifying from Loveridge (1973) [13]. The total amount of lipids stored in each pupae was determined with chloroform extraction by three times, 24-h changes of chloroform [13]. At the end of the third chloroform wash they were re-dried and re-weighed to calculate lipid content.

The lipid-free pupae were analyzed for their nitrogen content using Thermo Scientific Flash 2000 series-NCS analyzer instrument by Dumas method [14]. Dried samples weighed approximately $2.5 \mathrm{mg}$ in tiny containers. Samples introduced into the combustion reactor via the Thermo Scientific TM MAS Plus Autosampler with the oxygen determined by the proprietary Thermo Scientific OxyTune ${ }^{\circledR}$ feature. It allows the automated evaluation of the oxygen needed for combustion, according to the weight and nature of the sample. After combustion, the produced gases are carried by a helium flow to a second reactor filled with copper, then swept through $\mathrm{CO} 2$ and $\mathrm{H} 2 \mathrm{O}$ traps, a GC column. Finally they are detected by a Thermal Conductivity Detector. At the end of this process, the amounts of $\%$ nitrogen were multiplied by the constant of 6.25 to convert to the crude protein quantities [15].

\subsection{Statistical Analysis}

The amount of food consumption by each larva fed on each artificial diet, the pupal dry weight, protein and lipid amounts in the pupae were analyzed statistically using the SPSS 17 version. A normality test was performed to determine whether the variables were normally distributed. Then ANOVA and then TUKEY test were performed to determine whether the variables differed. A Pearson correlation test was performed to determine whether there was an association between variables.

\section{Results}

There was a clear effect of different carbohydrates and tannin on the food consumption and growth performance of larvae (Figure 1). As a remarkable result; among the tannin-free diets, it was determined that the most consumption amount was found in the larvae fed with the dietary intake of arabinose. The minimum consumption is in the diet containing mannose (Figure 1). According to the results of the ANOVA test, differences were found between consumption quantities of the different food types $(\mathrm{F}=222149,93, \mathrm{p}<, 001)$. According to the TUKEY test results, the consumption amounts of the larvae on the artificial diets were statistically different from each other (Figure 1).

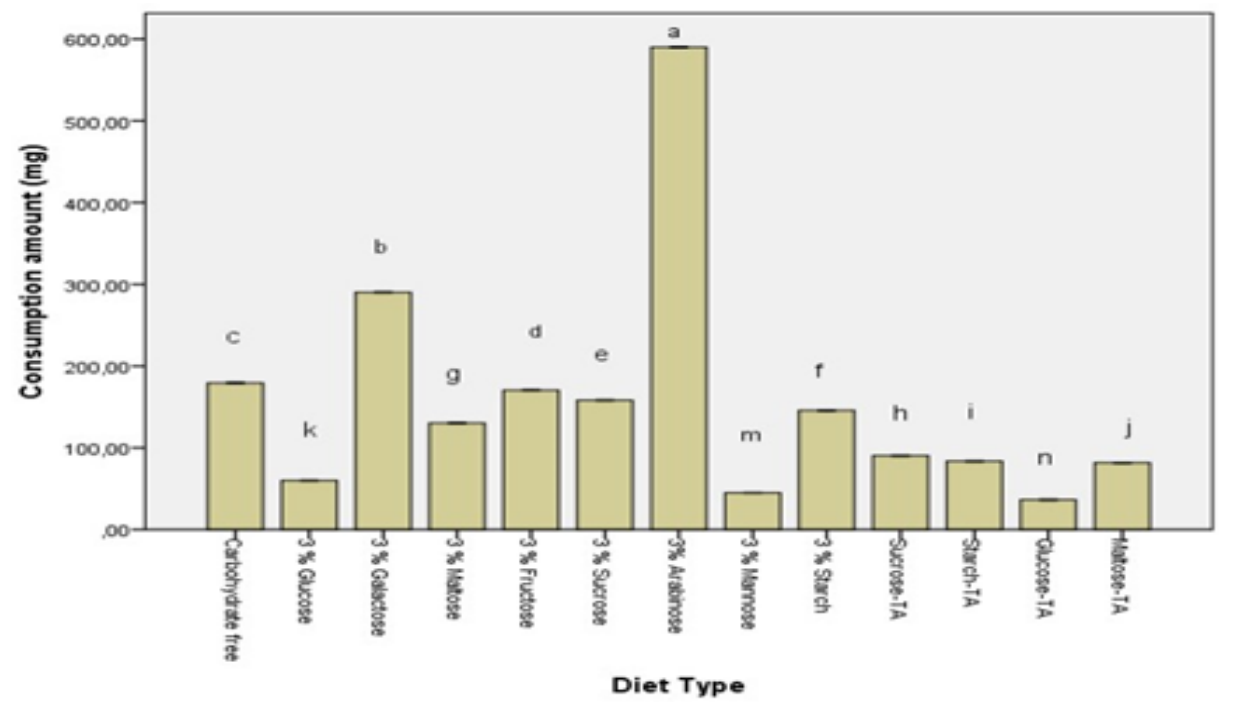

Figure 1. Food consumption on different artificial diet $(\mathrm{mg})$. *Diets with the same letter are not significantly different 
Larval diet treatment had a significant effect on pupal dry weight (ANOVA: $F=6059.47, \mathrm{p}<0.01$ ). The highest dry weight of pupa in diets containing no secondary metabolite was determined in the diet containing mannose. The lowest pupae is dry weight in the galactose-containing diet (Figure 2). Although the consumption of larvae fed on glucose-containing diets was low, it is noteworthy that the pupae dry weight was high. According to the results of TUKEY test, dry weight of pupa in all diets, except for maltose $+\mathrm{T}$; sucrose + TA and starch + TA, diet is different from each other (Figure 2). Pearson correlation test results show that there is a weak relationship between food consumption and pupa dry weight $(\mathrm{R}=0.376 ; \mathrm{P}<0.01)$.

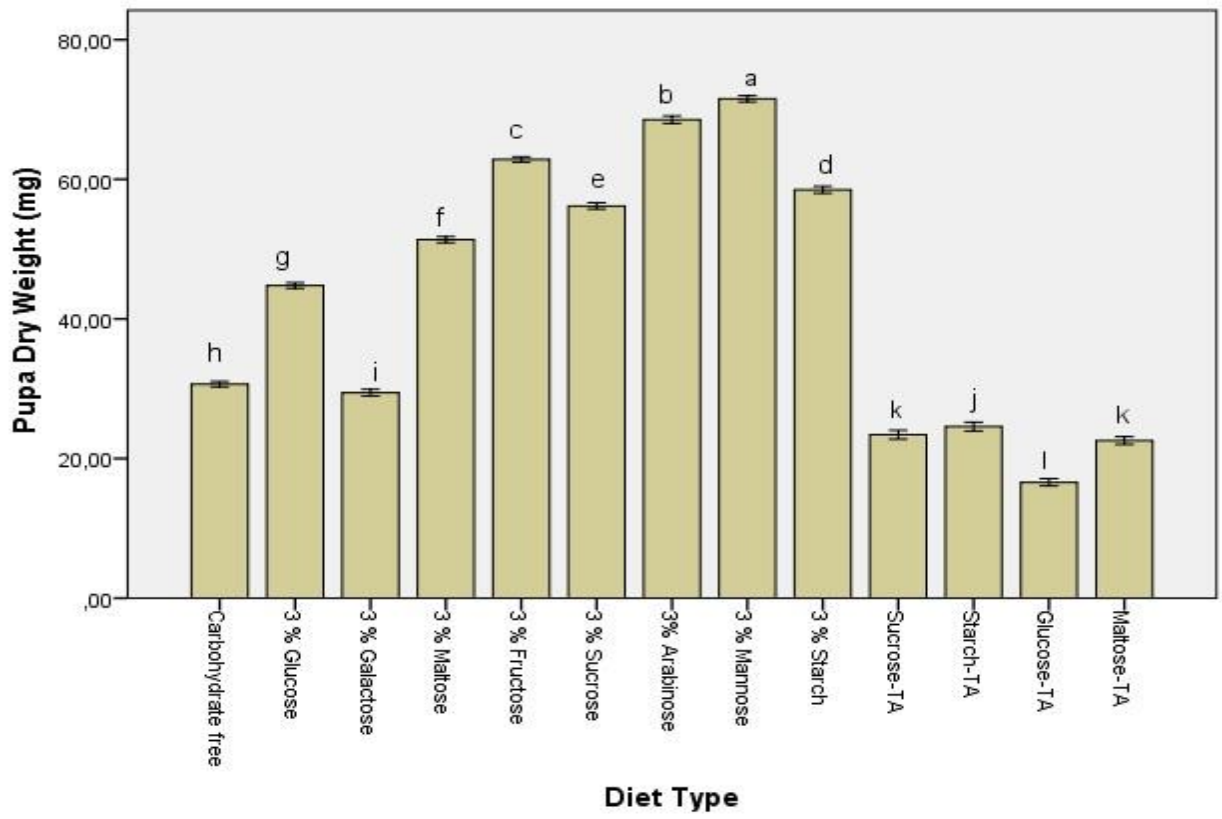

Figure 2. Pupa dry weight on different artificial diet (mg). *Diets with the same letter are not significantly different

When the pupal protein contents were calculated, the highest value was obtained with the pupae of the larvae fed on the artificial diet containing starch and the lowest value was measured as expected in the pupae of the larvae fed on the artificial diet having no carbohydrate. The lowest value was determined on the artificial diet containing glucose (Figure 3). The results of the ANOVA test show that there is a difference between the amounts of pupae protein in the treatments $(\mathrm{F}=214.34 ; \mathrm{p}<0.01)$.

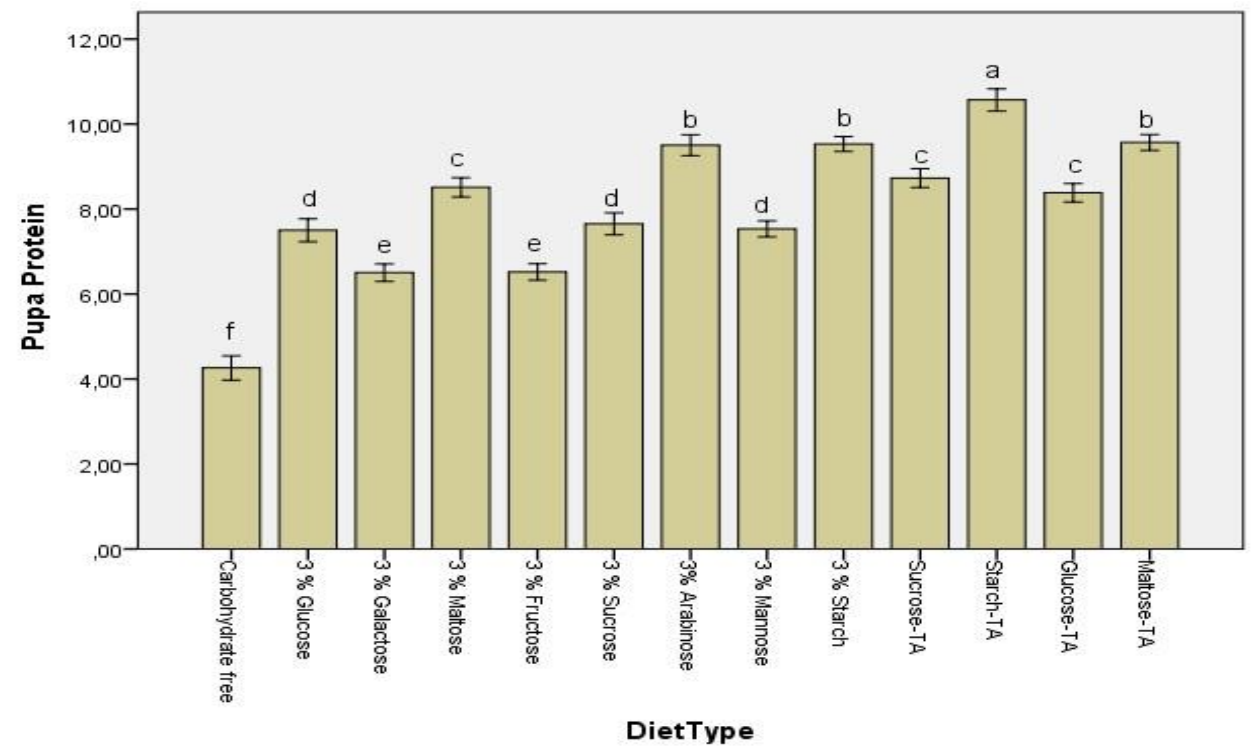

Figure 3. Pupa crude protein on different artificial diet. *Diets with the same letter are not significantly different

Among the tannin-free diets, the highest pupal lipid amount was determined for larvae consuming galactose and the lowest pupae lipid amount was determined for glucose-consuming larvae. (Figure 4). A significant difference was determined between the amounts of pupae lipids of larvae fed on different artificial diets (ANOVA: F=461.62; 
$\mathrm{p}<0.01)$. According to the results of the TUKEY test, the pupae lipid amounts for larvae consuming arabinose, mannose or glucose + TA do not differ from each other. Similar results have been found for diets containing maltose + TA, starch + TA, and fructose, maltose or starch. According to Pearson correlation test results, there is a weak negative correlation between the amount of pupae lipid and food consumption $(R=-0.233 ; p<0.01)$. There is a weak positive correlation between the amount of pupae lipid and pupal protein amount $(\mathrm{R}=0.280 ; \mathrm{P}<0.01)$. Similarly, it was determined that the pupa dry weight affects the amount of pupa lipid positively $(R=0.0489 ; p<0.01)$.

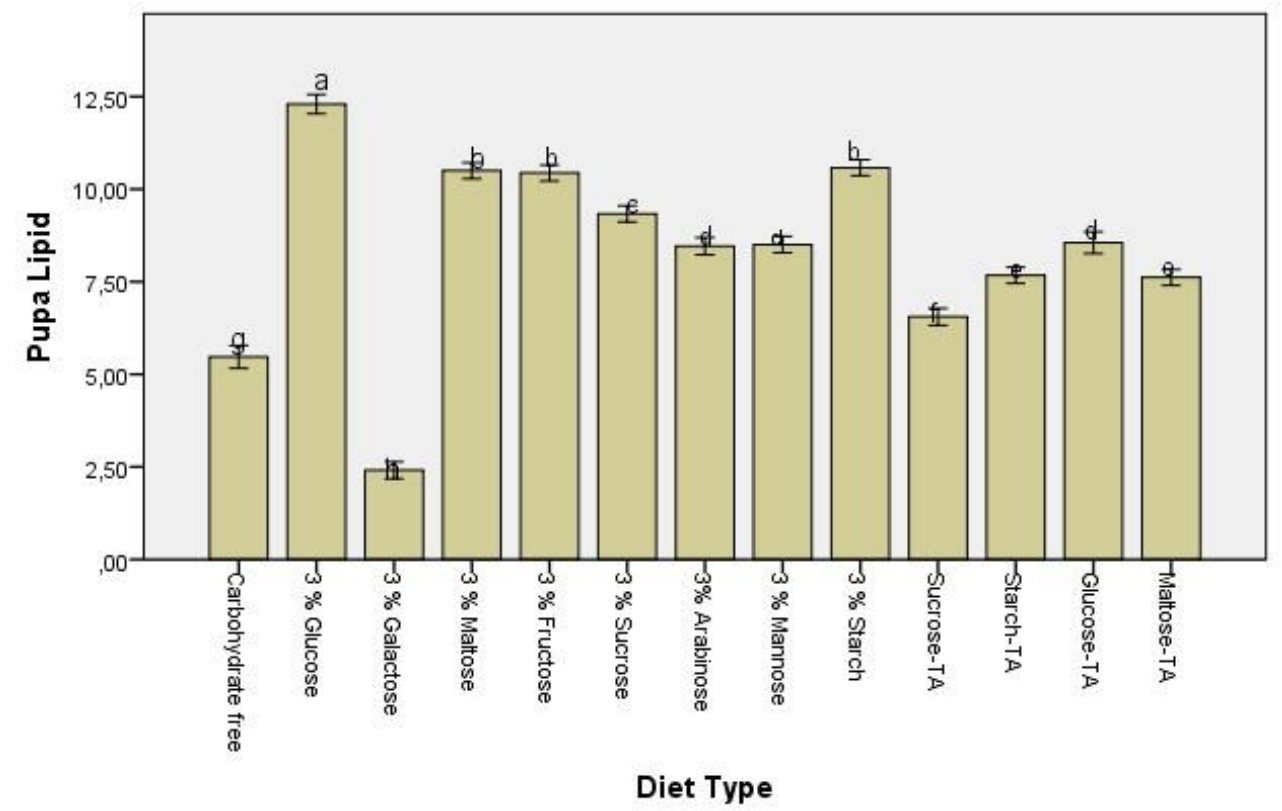

Figure 4. Pupa lipid amount on different artificial diet (mg). *Diets with the same letter are not significantly different

The duration of larval development varies between artificial diets (ANOVA: F=166.09; $\mathrm{P}<0.01$ ). Among tannic acid free diet, it was determined that the longest larval stage length was in the larvae fed on the artificial diet containing no carbohydrate; the shortest larval period was in the larvae fed on the artificial diet containing mannose (Figure 5). The analyses of these data by TUKEY test showed that there was no significant difference between the developmental stage length of the larvae fed on the artificial diets containing mannose or arabinose. Similarly, there was no difference between the length of larval stage fed on the artificial diets containing arabinose or galactose. The developmental stages of the larvae fed on the artificial diets containing mannose or galactose were different from each other (Figure 5).

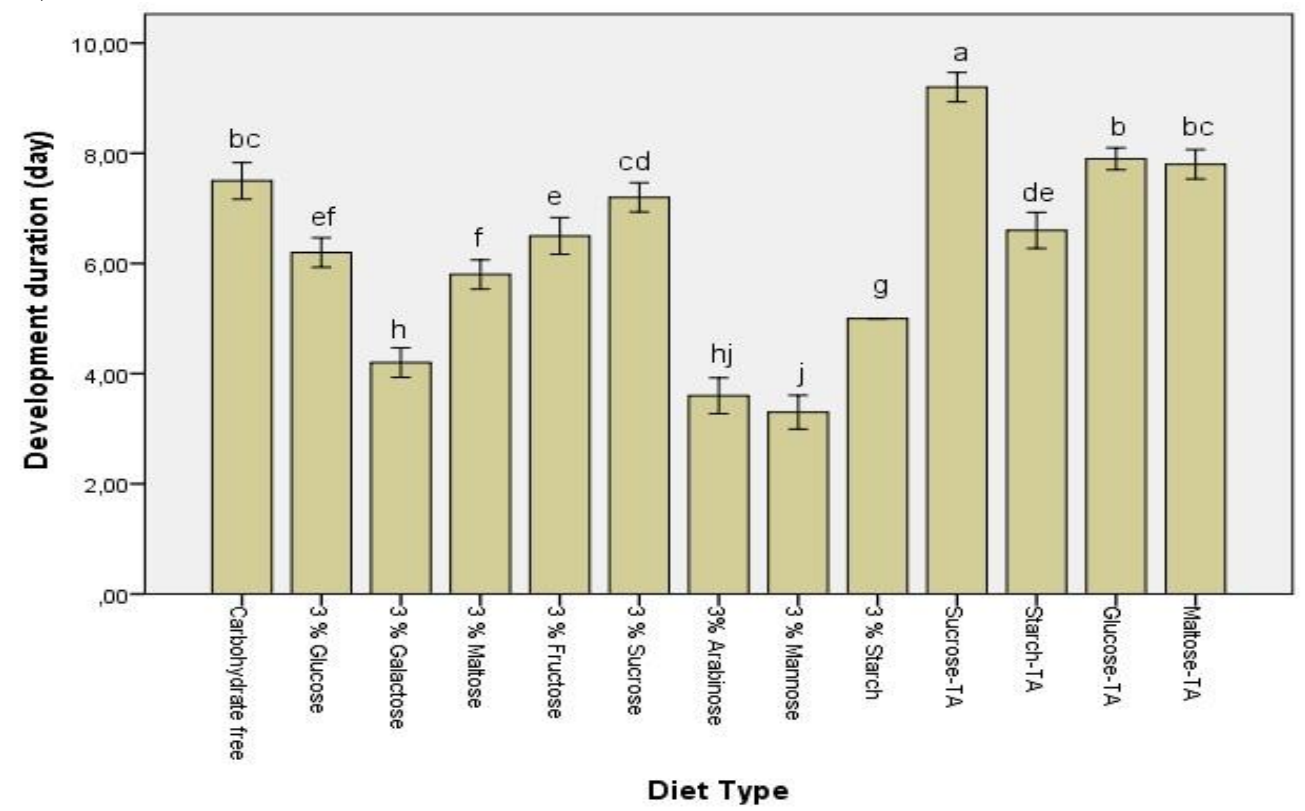

Figure 5. Larval development duration on different artificial diet. *Diets with the same letter are not significantly different 
A Pearson correlation test results show that there is a negative correlation between food consumption and development duration $(\mathrm{R}=-0.0484 ; \mathrm{p}<0.01)$. It was found out that as the food consumption amount decreased, the duration of growth increased. Similarly, there was a negative correlation between pupal dry weight and development duration $(\mathrm{R}=-0.665 ; \mathrm{p}<0.01)$. As the duration of the larval development was prolonged, the pupae weight were decreased.

It was determined that the amount of food consumption, pupa dry weight, and pupa lipid amount decreased with the addition of tannic acid to artificial diet. However, the amount of pupa protein increased with the addition of tannic acid, and the development time was prolonged.

\section{Conclusions and discussion}

In the literature, sucrose is indicated as a more preferred carbohydrate than glucose and fructose $[16 ; 17 ; 18]$. In our study, sucrose was consumed more than glucose and fructose. However, it cannot be said that glucose is more preferred by $U$. gilvata larvae than fructose. Also, the fructose consumption or the arabinose consumption is higher than the sucrose consumption by $U$. gilvata larvae. Therefore, the stimulatory effect of arabinose and fructose to $U$. gilvata larvae may be greater than that of sucrose. Also, our results differ from the literature. Many studies have pointed out that some carbohydrates act as a phagostimulants to insects [18; 19]. The continuation of feeding depends on the continuation of feeding stimulants [19]. The more stimulating the effect, the more nutrient consumption will be too much [19]. Fructose is a feeding stimulant for many insects. Jiang (2015) [20] stated that D-fructose stimulates the gustatory receptor in antennas. Therefore, fructose has also been a feeding stimulant for U. gilvata larvae. It has been determined that the pupal lipid ratios of the larvae fed with fructose are also high. Fructose has effects on glycogenesis and several lipogenic enzyme systems [21]. Therefore fructose may have stimulated lipid storage in larvae.

Although arabinose is a sugar which is toxic to many insect species and can be used as an insecticide [22], interestingly, $U$. gilvata larvae an more consume. Carbohydrates which have toxic effects cause changes in the insect cuticula, dry the cuticula or block the spiracles and cause them to suffocate [23]. High concentrations of arabinose play as lectin in members of the Solanaceae family and are not digested by insects [24], even if carbohydrates have a toxic effect for the development of insects, sugar transport across the gut epithelium into their cells with sugar transport molecules [25]. No toxic effect of arabinose on $U$. gilvata larvae was detected. The larvae may have used the arabinose to complete their development.

Some carbohydrates could be feeding deterrents to insects [3]. The deterrent carbohydrates cannot be hydrolyzed or absorbed in the insects' guts. But some carbohydrates can be absorbed but not metabolized in the insects' bodies. According to our results, galactose could be a feeding stimulant for the U. gilvata larvae, but it may not be metabolized in their body. Because galactose is converted to galactitol [3]. This alcohol may be metabolized by $U$. gilvata larvae and accumulates in the hemolymph.

Although $U$. gilvata larvae consumed the mannose-containing artificial diet quite low, the pupae dry weight turned out to be the highest on the artificial diet containing this sugar. Another remarkable result is that the developmental stage length does not differ from that of the larvae fed on the arabinose-containing artificial diet, which had the highest amount of consumption. Mannose may be absorbed and used by $U$. gilvata larvae although it was consumed in small quantity.

It is noteworthy that the consumption of the glucose-containing artificial diet by $U$. gilvata larvae was low, but especially the pupae lipid content was quite high. Circulating glucose in the hemolymph is rapidly converted into trehalose in the fat body by the enzyme trehalose-6-phosphate synthase [26]. Glucose is stored as glycogen in a polymeric form in animal bodies. Glycogen is synthesized from UDP-glucose mainly derived from dietary carbohydrates or amino acids. UDP-glucose can be used for the synthesis of either glycogen or trehalose, the circulating sugar in the hemolymph. When fat body trehalose reaches a certain level, its synthesis is inhibited, and UDP-glucose is used for glycogen synthesis. Lipids are the main fat body components, and more than $90 \%$ of the lipids stored are triglycerides. Triglycerides are synthesized from dietary carbohydrates, fatty acids, or proteins [26]. Therefore, the excess amount of pupal lipids fed on the glucose-containing artificial diets may be converted to the glucose into the fat body.

It has been determined that the consumption of $U$. gilvata larvae fed on the carbohydrate-free artificial diet was in the 3rd rank following those artificial diet containing arabinose or galactose. It is remarkable that the pupal dry weight, protein and lipid contents in pupal body were quite low, the development period length was longer on this diet. Therefore, it can be concluded that carbohydrate is essential for the development of U. gilvata larvae.

According to our results, there is a negative correlation between the amount of consumed food and the duration of development. Insects have the capacity to tolerate the decline in nutrient concentrations. The decrease in the nutrient concentrations is tolerated by $U$. gilvata larvae, either by increasing the food consumption [27] or by changing the food use efficiency. U. gilvata larvae may have increased the consumption of the carbohydrate-free artificial diet to provide the needed nutrients. Low pupal dry weight, low protein and lipid content can be caused by using the protein from the diets as an energy source through glycogenesis to meet the carbohydrate needs of the larvae [12]. Nash and Chapman 
[28] suggested that carbohydrates, especially starch, lactose, maltose, and glucose, have no effect on the development length of the larvae. Our results differ from that of Nash and Chapman's suggestion in this respect. The correlation results indicating a negative relationship between the duration of development and the pupal dry weight. The larvae would spend more energy on feeding as the duration of the development increases. This may have caused the pupal dry weight to decrease.

When tannin was added to the artificial diets containing different carbohydrates at a concentration of $5 \%$, the food consumption by the larvae was reduced compared to the artificial diet containing the same carbohydrates without tannin. In herbivores that are not adapted to tannins as a nutritional deterrent in their foods, the adverse effects of tannins could come out as by binding to digestive enzymes in the intestines of animals, creating lesions in the intestinal epithelium, causing oxidative stress and the formation of semiquinone radicals, destroying microbial symbiotic communities and exhibiting pharmacological toxic effects [29]. Therefore, the decreases in the food consumption by the larvae when tannin added to the artificial diets are the results of the conditions mentioned in the literature [30]. The results of this study demonstrated that the pupal dry weights and the lipid contents of the pupae fed on the artificial diets containing tannin, have decreased. Lower results of the pupal dry weight by the addition of tannin to the artificial diet support the study carried out with some species $[13 ; 31 ; 32-33]$. The emergence of semiquinone radicals when tannin ingested in artificial diets may have increased the metabolic cost and reduced the conversion efficiency of the consumed food to body mass [32]. Mrdakovic et al. [34] determined that high lipase activity was observed in the larvae of Lymantria dispar as a reaction to tannin. The reason for a decrease in the pupae lipid content of $U$. gilvata species by the addition of tannin to the artificial diet may cause higher lipase activities. According to our results, an increase in the protein content of pupa was detected by the addition of tannin to the artificial diet. This result obtained from our study supports the studies of Simpson and Raubenheimer [13]. During the plant-herbivore coevolution, encounters of herbivores with various adverse secondary compounds may have triggered the ability to stored proteins in herbivores' bodies [35]. The developmental lengths of the larvae were prolonged with the addition of tannin to the artificial diet according to our results. Tannin may have also prolonged the developmental period of the larvae as it causes the inhibition of digestive enzymes and affecting the usability and convertibility of nutrients, causing lesions in the digestive tract. This may explain why larvae feed on herbaceous forms, despite the presence of woody forms of tannin in the habitat. Larvae may be fed with $S$. alopecuroides to avoid adverse effects of tannin and to avoid competition.

In conclusion; arabinose exhibiting a toxic effect on many insects but no toxic effect for $U$. gilvata larvae. The amount of galactose consumed was quite higher that it may be a nutritional stimulant for $U$. gilvata larvae, but galactose may not be metabolized by $U$. gilvata larvae. It could be summarized that the food consumptions, dry weights and lipid contents of pupae were decreased, but the amount of the protein in pupa was increased when the larvae fed the artificial diets having tannin when compared with other sugar type. Therefore our results regarding with tannin can shed light on co-evolution.

\section{Acknowledgements}

This study was conducted as a master thesis at Ondokuz May1s University. Furthermore, it was presented as an poster presentation at the XII. Ulusal Ekoloji ve Çevre Kongresi, , 14-17 Eylül 2015, Muğla, TURKEY.

\section{References}

[1] Stam, J. M., Kroes, A., Li, Y., Gols, R., van Loon, J. J. A., Poelman, E. H. \& Dicke, M. (2014). Plant interactions with multiple insect herbivores: from the community to genes. Annual Review of Plant Biology, 65 (1), 689-713.

[2] Coyle, D.R., Clark, K.E., Raffa, K.F. \& Johnson, S.N. (2011). Prior host feeding experience influences ovipositional but not feeding preference in a polyphagous insect herbivore. Entomologia Experimentalis et Applicata, 138 (2), 137-145.

[3] Rockstein, M. (1978). Biochemistry of Insects. 1-55. NewYork: Academic Press.

[4] Gündüz, E. A., Gl, A., Varer Işıtan, Ö., Boz, A. \& Cesur, Ö. (2010). Effects of sugar feeding on lipid, glycogen, and total sugar levels of a female parasitoid, Bracon hebetor (Say) (Hymenoptera: Braconidae): Turkish Journal of Agriculture and Forestry, 34, 343-347.

[5] Sarwar, M. (2009). Populations' synchronization of aphids (Homoptera: Aphididae) and ladybird beetles (Coleoptera: Coccinellidae) and exploitation of food attractants for predator: Biological Diversity and Conservation, 2, 85-89.

[6] Kaufmann, C., Mathis, A. \& Vorburger, C. (2015). Sugar-feeding behaviour and longevity of European Culicoides biting midges: Medical and Veterinary Entomology, 29, 17-25. https: // doi: 10.1111/mve.12086.

[7] Bernklau, E. J., Hibbard, B. E. \& Bjostad, L. B. (2018). Sugar preferences of western corn rootworm larvae in a feeding stimulant blend: Journal of Applied Entomology, 142, 947-958. 
[8] Barbehenn, R.V. \& Constabel, P.C. (2011). Tannins in plant-herbivore interactions: Phytochemistry, 72 (13), 1551-1564.

[9] Monteys, V. S. (2002). Nueva planta alimenticia para Uresiphita gilvata (Lep. Crambidae) y nuevo parasitoide bracónido (Hym.) de ésta : Phytoma, 138, 43-45.

[10] Can, Ö. \& Taş, B. (2012). Ecological and socio-economic importance of Cernek Lake and wetland area (Kızılırmak Delta, Samsun) located in Ramsar area: TÜBAV Bilim Dergisi 5 (2), 1-11.

[11] Yamamoto, R. T. (1969). Mass rearing of tobacco hornworm. II. Larval rearing and pupation: Journal of Economical Entomology, 62, 1427-1431.

[12] Lee, K. P., Behmer, S. T., Simpson, S. J. \& Raubenheimer, D. (2002). A geometric analysis of nutrient regulation in the generalist caterpillar Spodoptera littoralis (Boisduval). Journal of Insect Physiology, 48 (6), 655-665.

[13] Simpson, S. J. \& Raubenheimer, D. (2001). The geometric analysis of nutrient-allelochemical interactions: a case study using locusts. Ecology, 82, 422-439.

[14] Yi, L., Lakemonda, C. M. M., Sagisb, L. M. C., Eisner-Schadlerc, V., van Huisd, A. \& van Boekela, M. A. J. S. (2013). Extraction and characterization of protein fractions from five insect species. Food Chemistry, 141, 33413348.

[15] Oonincx, D. A. G. B., Van Broekhoven, S., Van Huis, A. \& Van Loon, J. J. A. (2015). Feed conversion, survival and development and composition of four insect species on diets composed of food by-products. PLoS One, 10 (12), 1-20. https:// doi:10.1371/ journal.pone.0144601.

[16] Cornelius, M.L., Grace, J.K. \& Yates, J.R. (1996). Acceptability of different sugars and oils to three tropical ant species (Hymen.: Formicidae). Anzeiger für Schädlingskunde, Pflanzenschutz, Umweltschutz, 69, 41 - 43.

[17] Blüthgen, N. \& Fiedler, K. (2004). Preferences for sugars and amino acids and their conditionality in a diverse nectar-feeding ant community. Journal of Animal Ecology, 73 (1), 155-166.

[18] Juma, G., Thiongo, M., Dutaur, L., Rharrabe, K., Marion-Poll, F., Le, Ru. B., Magoma, G., Silvain, J. F. \& Calatayud, P. A. (2013). Two sugar isomers influence host plant acceptance by a cereal caterpillar pest. Bulletin of Entomological Research, 103, 20-28.

[19] Bernays, E.A., Chapman, R.F. \& Singer, M.S. (2004). Changes in taste receptor cell sensitivity in a polyphagous caterpillar reflect carbohydrate but not protein imbalance. Journal of Comparative Physiology A, 190 (1), 39-48.

[20] Jiang, X.J., Ning, C., Guo, H., Jia, Y. Y., Huang, L.Q., Qu, M. J. \& Wang, L. Q. (2015). A gustatory receptor tuned to D-Fructose in antennal sensilla chaetica of Helicoverpa armigera. Insect Biochemistry and Molecular Biology, (60), 39-46.

[21] Thompson, S. N. (1981). Effects of Dietary Carbohydrate and Lipid on Nutrition and Metabolism of Metazoan Parasites with Special Reference to Parasitic Hymenoptera. In: Bashkaran, G., Friedman, S. \& Rodriguez, J. G. (Eds), Current Topics in Insect Endocrinology and Nutrition (1 st ed., pp. 215-252). New York and London: Plenum Press

[22] Hu, J. S., Gelman, D. B., Salvucci, M. E., Chen, Y. P. \& Blackburn, M. B. (2010). Insecticidal activity of some reducing sugars against the sweet potato whitefly, Bemisia tabaci, Biotype B. Insect Science, 10 (203), 1-22.

[23] Puterka, G.J., Farone, W., Palmer, T. \& Barrington, A. (2003). Structure-function relationships affecting the insecticidal and miticidal activity of sugar esters. Journal of Economical Entomology, 96, 636-644.

[24] Hilder, V. A., Gatehouse, A. M. R., Sheerman, S. E., Barker, R. F. \& Boulter, D. (1987). A novel mechanism of insect resistance engineered into tobacco. Nature, 330, 160-163.

[25] Price, D. R. G., Tibbles, K., Shigenobu, S., Smertenko, A., Russell, C. W., Douglas, A. E., Fitches, E., Gatehouse, A. M. R. \& Gatehouse, J. A. (2010). Sugar transporters of the major facilitator superfamily in aphids; from gene prediction to functional characterization. Insect Molecular Biology, 19, 97-112.

[26] Arrese, E. L. \& Soulages, J. L. (2010). Insect fat body: Energy, Metabolism and Regulation. Annual Review of Entomology, 55, 207-225.

[27] Raubenheimer, D. (1992). Tannic asit, protein and digestible carbohydrate: dietary imbalance and nutritional compensation in the African migratory locust: Ecology, 73, 1012-1927.

[28] Nash, W. J. \& Chapman, T. (2014). Effect of dietary components on larval life history characteristics in the Medfly (Ceratitis capitata: Diptera, Tephritidae): PLoS One, 9(1), e86029.

[29] Mole, S. \& Waterman, P. G. (1987). Tannins as antifeedants to mammalian herbivores — still an open question, In Waller, G. R. (Eds), Allelochemicals: role in agriculture and forestry (72-587). Washington, D.C., USA: ACS Symposium Series, American Chemical Society. 
[30] Kubo, I., Hori, I., Nihei, K-I., Satooka, H., Cèspedes, C. L. \& Calderon, J. (2008). Insect growth inhibitory activity and cytotoxicity of tannic acid from Gallae rhois. Biopesticides International, 4 (1), 6-14.

[31] Liu, W., Xue, C. B., Zhang, J. J., Yu, J. F. \& Luo, W. C. (2010). Inhibitory effect of tannic acid on growth, development and phenoloxidase activity of Spodoptera exigua larva. Journal of Plant Resources and Environment, 19 (1), 32-37.

[32] Barbehenn, R. V., Jaros, A., Lee, G., Mozola, C., Weir, Q. \& Salminen, J. P. (2009). Hydrolyzable tannins as "quantitative defenses": limited impact against Lymantria dispar caterpillars on hybrid poplar. Journal of Insect Physiology, 55, 297-304. https://doi: 10.1016/j.jinsphys.2008.12.001.

[33] Hemming, J. D.C. \& Lindroth, R. L. (1995). Intraspecific variation in aspen phytochemistry: effects on performance of gypsy moths and forest tent caterpillars. Oecologia, 103, 79-88.

[34] Mrkadovic, M., Peric Mataruga, V., Ilijin, L., Vlahovic, M., Jankovic Tomanic, M., Mircic, D. \& Lazarevic, J. (2013). Response of Lymantria dispar (Lepidoptera: Lymantriidae) larvae from differently adapted populations to allelochemical stress: Effects of tannic acid. European Journal of Entomology, 110 (1), 55-63.

[35] Bernays, E.A. (1998). Evolution of feeding behaviour in insect herbivores. Bioscience, 48 (1), 35-44. 